\title{
BEBERAPA SIFAT BAMBU LAMINA \\ YANG TERBUAT DARI TIGA JENIS BAMBU
}

(Some Properties of Laminated Bamboo Board made from Three Bamboo Species)

Oleh/By:

I.M. Sulastiningsih

\section{ABSTRACT}

This study investigated the potential of laminated bamboo board as a wood substitute, with particular focus on the effects of bamboo species on some properties of laminated bamboo board glued with urea formaldehyde. The bamboo species applied in these tests were andong (Gigantochloa pseudoarundinacea), mayan (Gigantochloa robusta) and tali (Gigantochloa apus) collected from private gardens in West Java.

Results showed that some properties of laminated bamboo board were affected by bamboo species except moisture content, compression strength parallel to grain and bonding strength. The density of laminated bamboo board varied from 0.60 $0.77 \mathrm{~g} / \mathrm{cm}^{3}$. The laminated bamboo board made from tali had the highest bending strength while laminated bamboo board made from mayan had the lowest bending strength. The bonding strength of laminated bamboo board of dry and wet samples varied from $67.03-86.19 \mathrm{~kg} / \mathrm{cm}^{2}$ and $54.43-62.92 \mathrm{~kg} / \mathrm{cm}^{2}$ respectively. Three-layer thick laminated bamboo board made from those three bamboo species had comparable strength to wood strength class II. Production of laminated bamboo board is technically feasible and it will provide an alternative wood source.

Keywords: Bamboo, laminated bamboo board, urea formaldehyde, physical and mechanical properties, bonding strength 


\begin{abstract}
ABSTRAK
Penelitian ini bertujuan untuk mempelajari kemungkinan penggunaan bambu lamina sebagai bahan substitusi kayu, khususnya mengetahui pengaruh jenis bambu terhadap sifat bambu lamina yang direkat dengan urea formaldehida. Bambu yang digunakan dalam penelitian ini adalah bambu andong (Gigantochloa pseudoarundinacea), bambu mayan (Gigantochloa robusta) dan bambu tali (Gigantochloa apus) yang berasal dari tanaman rakyat di Jawa Barat.

Hasil penelitian menunjukkan bahwa beberapa sifat bambu lamina dipengaruhi oleh jenis bambu yang digunakan kecuali kadar air, keteguhan tekan sejajar serat dan keteguhan rekat. Kerapatan bambu lamina bervariasi antara 0,62 - 0,79 g/ $\mathrm{cm}^{3}$. Bambu lamina dari bambu tali memiliki nilai keteguhan lentur tertinggi sedangkan bambu lamina dari bambu mayan memiliki keteguhan lentur terendah. Keteguhan rekat bambu lamina yang diuji dengan cara geser tekan bervariasi antara 67,03 - 86,19 kg/ $\mathrm{cm}^{2}$ dan $54,43-62,94 \mathrm{~kg} / \mathrm{cm}^{2}$ berturut-turut untuk uji kering dan uji basah. Sifat perekatan bambu lamina dari bambu andong, mayan dan tali cukup baik. Bambu lamina (3 lapis) masing-masing dari bambu andong, mayan dan tali setara dengan kayu kelas kuat II. Pembuatan bambu lamina secara teknis dapat dilakukan dan produk tersebut dapat digunakan sebagai bahan substitusi kayu.
\end{abstract}

Kata kunci: Bambu, bambu lamina, urea formaldehida, sifat fisis dan mekanis, keteguhan rekat 


\section{PENDAHULUAN}

Indonesia sebagai salah satu negara tropis di dunia memiliki sumber daya bambu yang cukup potensial. Sumber daya bambu yang cukup melimpah tersebut perIu ditingkatkan pemanfaatannya agar dapat memberi sumbangan terhadap pertumbuhan ekonomi nasional. Pemanfaatan bambu di Indonesia saat ini pada umumnya untuk mebel, barang kerajinan, supit dan konstruksi ringan. Bambu yang digunakan untuk mebel biasanya berbentuk bulat atau kombinasi antara bambu bulat dan anyaman yang masih ada kulitnya. Sementara itu pasokan kayu baik untuk bahan baku industri pengolahan kayu maupun untuk bahan bangunan dan mebel sangat tidak mencukupi. Hal ini terjadi karena kecepatan pemanfaatan kayu tidak seimbang dengan kecepatan pembangunan tegakan hutan. Sementara itu kebutuhan kayu untuk mebel, bahan bangunan dan keperluan lain terus meningkat seiring dengan pertambahan penduduk serta sebagai pengganti kayu yang rusak, lapuk atau dimakan rayap.

Jumlah penduduk Indonesia pada tahun 2005 adalah 219,2 juta jiwa dengan kecepatan pertambahan penduduk 1,34\% per tahun (Anonim, 2006). Sementara itu menurut Supriana et al. (2003) kebutuhan rumah di Indonesia per tahun adalah 2,9 juta unit dan kebutuhan kayu gergajian rata-rata tiap unit rumah adalah sekitar 2,97 $\mathrm{m}^{3}$ sehingga total volume kayu gergajian yang diperlukan untuk perumahan per tahun di Indonesia adalah sekitar 8,6 juta $\mathrm{m}^{3}$ atau setara dengan 17,2 juta $\mathrm{m}^{3}$ kayu bundar. Oleh karena itu perIu dicari bahan substitusi kayu khususnya sebagai bahan bangunan dan mebel. Bambu merupakan salah satu bahan yang dapat digunakan untuk tujuan tersebut karena sejak jaman dahulu manusia telah menggunakan bambu sebagai bahan bangunan, mebel, alat rumah tangga dan barang kerajinan.

Bambu yang termasuk tanaman cepat tumbuh dan mempunyai daur yang relatif pendek (3-4 tabun) merupakan salah satu sumber daya alam yang cukup menjanjikan 
sebagai bahan substitusi kayu. Sebagai bahan substitusi kayu, bambu harus memiliki dimensi tebal, lebar dan panjang seperti papan atau balok kayu. Masalah yang timbul dalam pemanfaatan bambu sebagai bahan substitusi kayu tersebut adalah keterbatasan bentuk dan dimensinya. Bambu yang bentuk aslinya bulat dan berlubang jika akan digunakan sebagai pengganti papan atau balok kayu harus memenuhi persyaratan lebar dan tebal tertentu. Dengan semakin majunya teknologi perekatan diharapkan dapat mengatasi keterbatasan bentuk dan dimensi bambu sebagai bahan substitusi kayu.

Dalam bentuk pipih bambu mempunyai ketebalan yang relatif kecil (tipis) sehingga untuk menambah ketebalannya perlu dilakukan usaha laminasi dengan menggunakan perekat tertentu. Di samping itu untuk mendapatkan produk bambu dengan ukuran seperti papan atau balok kayu maka bambu yang bentuk aslinya bulat dan diameternya semakin kecil ke arah ujung harus dibelah dengan alat tertentu sehingga diperoleh bilah yang lurus dan mudah direkat ke arah samping (lebar). Bilah yang dihasilkan kemudian diserut pada kedua permukaannya sehingga mudah direkat ke arah tebal. Hasil produk perekatan bilah bambu tersebut dikenal dengan nama bambu lamina.

Bambu lamina adalah suatu produk yang dibuat dari beberapa bilah bambu yang direkat dengan arah serat sejajar. Perekatan dilakukan ke arah lebar (horisontal) dan ke arah tebal (vertikal). Hasil perekatan tersebut dapat berupa papan atau balok tergantung dari ukuran tebal dan lebarnya. Dalam tulisan ini dikemukakan hasil penelitian beberapa sifat bambu lamina dari tiga jenis bambu. 


\section{BAHAN DAN METODE}

A. Bahan dan Alat

Bambu yang digunakan dalam penelitian ini adalah tiga jenis yaitu bambu andong (Gigantochloa pseudoarundinacea), bambu tali (Gigantochloa apus) dan bambu mayan (Gigantochloa robusta) yang berasal dari tanaman rakyat di Jawa Barat. Bahan pengawet yang digunakan adalah larutan boron (Borax dan Boric acid) dan perekat yang digunakan adalah Urea formaldehida (UF). Sedangkan peralatan yang digunakan dalam penelitian ini meliputi gergaji potong, alat belah bambu, mesin serut, mesin ampelas, masker, sarung tangan, bak perendaman, mixer (pengaduk perekat), klem/alat kempa dingin, mesin uji universal, oven, timbangan, kaliper, desikator dan peralatan gelas lainnya.

B. Metode

1. Pembuatan bilah bambu

Bambu yang digunakan untuk penelitian masing-masing dipotong bagian pangkalnya sepanjang $\pm 50 \mathrm{~cm}$ untuk menghilangkan bagian batang bambu dengan ruas yang tidak beraturan. Setelah dipotong bagian pangkalnya, batang bambu tersebut dipotong-potong menjadi beberapa bagian dengan panjang $\pm 1 \mathrm{~m}$. Batang bambu yang akan dibelah diukur diameternya dan tebal dindingnya. Batang bambu kemudian dibelah dengan bagian ujung (bagian yang diameternya lebih kecil) sebagai acuan lintasan pembelahan dengan menggunakan alat belah bambu $\mathrm{P} 3 \mathrm{HH}$ hasil rekayasa tahun 2003. Banyaknya bilah bambu yang dihasilkan tergantung dari besarnya diameter bambu yang dibelah. Bilah bambu hasil pembelahan selanjutnya diserut pada bagian atas dan bawah untuk mendapatkan permukaan bilah yang rata. Bilah bambu yang telah diserut kedua permukaannya kemudian diawetkan dengan larutan boron 5\% dengan cara 
rendaman dingin selama 2 jam kemudian dikeringkan dengan sinar matahari hingga kadar airnya mencapai $\pm 12 \%$.

\section{Pembuatan bambu lamina}

Bambu lamina dibuat dengan merekat beberapa bilah bambu yang sudah kering ke arah lebar dan ke arah tebal menggunakan perekat urea formaldehida cair. Ke dalam perekat tersebut ditambahkan ekstender (tepung terigu) sebanyak 15\% dan pengeras 1\% dari berat perekat cair. Bambu lamina yang dibuat terdiri dari 3 lapis dan berukuran 15 cm x 100 cm (pxl) tebalnya tergantung dari tebal bilah bambu yang digunakan. Berat labur perekat $170 \mathrm{~g} / \mathrm{m}^{2}$ permukaan. Bahan bambu lamina dikempa dingin/diklem dengan lama waktu pengempaan 3 jam. Untuk masing-masing perlakuan dibuat bambu lamina sebanyak 3 buah. Bambu lamina yang sudah jadi kemudian dikondisikan selama 1 minggu. Bambu lamina yang dihasilkan kemudian diukur dimensinya dan diamati penampilannya serta diuji sifat fisis dan mekanisnya. Pengujian sifat fisis bambu lamina meliputi kadar air, kerapatan, pengembangan tebal, pengembangan linier dan penyerapan air dilakukan menurut Standar Amerika (ASTM D 1037-93, Anonim 1995) dengan beberapa modifikasi. Sedangkan pengujian sifat mekanis meliputi keteguhan rekat uji kering (dengan geser tekan) dan keteguhan lentur dilakukan menurut Standar Jepang untuk kayu lamina (Anonim, 2003), sedangkan pengujian keteguhan tekan dilakukan menurut Standar Nasional Indonesia (Anonim, 1999). Adapun perlakuan contoh uji untuk keteguhan rekat uji basah mengikuti Standar Nasional Indonesia (Anonim, 2000). 


\section{Analisis Data}

Dari hasil pengujian sifat fisis dan mekanis bambu lamina dianalisis dengan menggunakan rancangan percobaan acak lengkap dan sebagai perlakuan adalah jenis bambu yaitu bambu andong, bambu mayan dan bambu tali. Banyaknya ulangan 3 buah.

\section{HASIL DAN PEMBAHASAN}

Hasil pengujian sifat fisis dan mekanis bambu lamina tercantum dalam Tabel 1. Untuk mengetahui pengaruh jenis bambu terhadap sifat bambu lamina dilakukan analisis keragaman dan hasilnya disajikan pada Tabel 2, sedangkan hasil uji bedanya tercantum dalam Tabel 3.

Kadar air rata-rata bambu lamina adalah 11,94\% dengan selang 11,78\% 12,05\%, jenis bambu tidak berpengaruh terhadap kadar air bambu lamina. Sedangkan kerapatan bambu lamina sangat dipengaruhi oleh jenis bambu yang digunakan. Kerapatan rata-rata bambu lamina adalah $0,71 \mathrm{~g} / \mathrm{cm}^{3}$ dengan selang $0,60-0,77 \mathrm{~g} / \mathrm{cm}^{3}$.

Bambu lamina dari bambu mayan mempunyai kerapatan terendah $\left(0,60 \mathrm{~g} / \mathrm{cm}^{3}\right)$ sedangkan bambu lamina dari bambu andong mempunyai kerapatan tertinggi $(0,77$ $\mathrm{g} / \mathrm{cm}^{3}$ ). Hasil uji beda pada Tabel 3 menunjukkan bahwa kerapatan bambu lamina dari bambu andong $\left(0,77 \mathrm{~g} / \mathrm{cm}^{3}\right)$ tidak berbeda nyata dengan kerapatan bambu lamina dari bambu tali $\left(0,76 \mathrm{~g} / \mathrm{cm}^{3}\right)$.

Kerapatan bambu lamina seperti halnya kerapatan produk komposit lainnya dipengaruhi oleh kerapatan atau berat jenis bahan penyusunnya, adanya perekat dan proses pengempaan. Kerapatan rata-rata bilah bambu tanpa kulit (sudah diserut kedua permukaannya) yang digunakan dalam penelitian ini berturut-turut adalah bambu andong $0,73 \mathrm{~g} / \mathrm{cm}^{3}$, bambu mayan $0,58 \mathrm{~g} / \mathrm{cm}^{3}$ dan bambu tali $0,71 \mathrm{~g} / \mathrm{cm}^{3}$. Menurut Dransfield dan Wijaya (1997) berat jenis bambu andong tanpa buku berkisar 0,5 - 0,7 dan dengan buku berkisar 0,6 - 0,8 , sedangkan berat jenis bambu mayan berkisar 0,38 
- 0,62 dengan rata-rata 0,55. Menurut Surjokusumo dan Nugroho (1994) berat jenis bambu andong dan bambu tali berturut-turut adalah 0,55 dan 0,65. Berdasarkan uraian di atas dapat diketahui bahwa kerapatan produk bambu lamina lebih tinggi daripada kerapatan bahan penyusunnya. Hal ini terjadi karena dalam pembuatan bambu lamina diperlukan perekat dan proses pengempaan untuk menyatukan bilah bambu penyusun bambu lamina.

Tabel 1. Nilai rata-rata beberapa sifat bambu lamina

Table 1. Mean values of some properties of laminated bamboo boards

\begin{tabular}{|c|c|c|c|}
\hline \multirow[b]{2}{*}{ Sifat (properties) } & \multicolumn{3}{|c|}{ Jenis bambu (Bamboo species) } \\
\hline & Andong & Mayan & Tali \\
\hline $\begin{array}{l}\text { Kadar air (Moisture } \\
\text { content), \% }\end{array}$ & 12,00 & 11,78 & 12,05 \\
\hline $\begin{array}{l}\text { Kerapatan (Density), } \\
\mathrm{g} / \mathrm{cm}^{3}\end{array}$ & 0,77 & 0,60 & 0,76 \\
\hline $\begin{array}{l}\text { Pengembangan tebal } \\
\text { (Thickness swelling),\% }\end{array}$ & 3,31 & 4,57 & 6,63 \\
\hline $\begin{array}{l}\text { Pengembangan linier } \\
\text { (Linear expansion),\% }\end{array}$ & 0,55 & 0,66 & 0,76 \\
\hline $\begin{array}{l}\text { Penyerapan air } \\
\text { (Water absorption), \% }\end{array}$ & 18,37 & 26,03 & 22,27 \\
\hline $\begin{array}{l}\text { Modulus patah } \\
\text { (Modulus of rupture), } \\
\mathrm{kg} / \mathrm{cm}^{2}\end{array}$ & $1.236,70$ & $1.107,24$ & $1.410,18$ \\
\hline $\begin{array}{l}\text { Modulus elastisitas } \\
\text { (Modulus of elasticity), } \\
\mathrm{kg} / \mathrm{cm}^{2}\end{array}$ & $361.154,3$ & 143.127 & $172.672,3$ \\
\hline $\begin{array}{l}\text { Keteguhan tekan sejajar } \\
\text { serat (Compression } \\
\text { strength parallel to } \\
\text { grain), } \mathrm{kg} / \mathrm{cm}^{2}\end{array}$ & 700,88 & 594,65 & 607,83 \\
\hline $\begin{array}{l}\text { Keteguhan tekan tegak } \\
\text { lurus serat (Compression } \\
\text { strength perpendicular to } \\
\text { grain), } \mathrm{kg} / \mathrm{cm}^{2}\end{array}$ & $1.408,40$ & $1.153,64$ & $1.328,68$ \\
\hline $\begin{array}{l}\text { Keteguhan rekat } \\
\text { (Bonding strength), } \\
\mathrm{kg} / \mathrm{cm}^{2} \\
\text { - Uji kering (Dry test) }\end{array}$ & 86,19 & 67,03 & 77,79 \\
\hline
\end{tabular}


- Uji basah (Wet test)

59,13

54,43

62,94

Pengembangan tebal bambu lamina dari tiga jenis bambu berkisar antara 3,31\% - 6,63\% dengan rata-rata 4,84\%. Pengembangan tebal bambu lamina sangat dipengaruhi oleh jenis bambu. Bambu lamina dari bambu andong memiliki nilai pengembangan tebal yang terendah sedangkan bambu lamina dari bambu tali memiliki nilai pengembangan tebal tertinggi.

Tabel 2. Nilai F hitung pengaruh jenis bambu terhadap sifat bambu lamina

Table 2. Calculated F values of the effect of bamboo species on laminated bamboo board properties

\begin{tabular}{|c|c|c|c|c|}
\hline \multirow[t]{2}{*}{ No } & \multirow[t]{2}{*}{ Sifat (Properties) } & \multirow{2}{*}{$\begin{array}{c}\mathrm{F}_{\text {hitung }} \\
\left(\mathrm{F}_{\text {calculated }}\right)\end{array}$} & \multicolumn{2}{|c|}{$\mathrm{F}_{\text {Tabel }}\left(\mathrm{F}_{\text {Table }}\right)$} \\
\hline & & & $\alpha=5 \%$ & $\alpha=1 \%$ \\
\hline 1 & Kadar air (Moisture content), \% & 0,12 & 5,14 & 10,92 \\
\hline 2 & Kerapatan (Density), g/cm ${ }^{3}$ & $85,29 * *$ & 5,14 & 10,92 \\
\hline 3 & $\begin{array}{l}\text { Pengembangan tebal (Thickness } \\
\text { swelling) ,\% }\end{array}$ & $6,25 *$ & 5,14 & 10,92 \\
\hline 4 & $\begin{array}{l}\text { Pengembangan linier } \\
\text { (Linear expansion),\% }\end{array}$ & $6,18^{*}$ & 5,14 & 10,92 \\
\hline 5 & $\begin{array}{l}\text { Penyerapan air } \\
\text { (Water absorption), \% }\end{array}$ & $9,47 *$ & 5,14 & 10,92 \\
\hline 6 & $\begin{array}{l}\text { Modulus patah } \\
\text { (Modulus of rupture), kg/cm² }\end{array}$ & $9,10^{*}$ & 5,14 & 10,92 \\
\hline 7 & $\begin{array}{l}\text { Modulus elastisitas } \\
\text { (Modulus of elasticity), } \mathrm{kg} / \mathrm{cm}^{2}\end{array}$ & $15,54 * *$ & 5,14 & 10,92 \\
\hline 8 & $\begin{array}{l}\text { Keteguhan tekan sejajar serat } \\
\text { (Compression strength parallel to } \\
\text { grain), } \mathrm{kg} / \mathrm{cm}^{2}\end{array}$ & 2,68 & 5,14 & 10,92 \\
\hline 9 & $\begin{array}{l}\text { Keteguhan tekan tegak lurus serat } \\
\text { (Compression strength } \\
\text { perpendicular to grain), } \mathrm{kg} / \mathrm{cm}^{2}\end{array}$ & $6,79 *$ & 5,14 & 10,92 \\
\hline 10 & $\begin{array}{l}\text { Keteguhan rekat } \\
\text { (Bonding strength), } \mathrm{kg} / \mathrm{cm}^{2} \\
\text { - Uji kering (Dry test) }\end{array}$ & 4,98 & 5,14 & 10,92 \\
\hline & - Uji basah (Wet test) & 1,42 & 5,14 & 10,92 \\
\hline
\end{tabular}


Keterangan (Remarks): * = Nyata (Significant); ${ }^{* *}=$ Sangat nyata (Highly significant)

Hasil uji beda pada Tabel 3 menunjukkan bahwa pengembangan tebal bambu lamina dari bambu andong (3,31\%) tidak berbeda nyata dengan pengembangan tebal bambu lamina dari bambu mayan (4,57\%). Hasil penelitian ini berbeda dengan hasil penelitian sebelumnya (Sulastiningsih et al., 2005) yang menunjukkan bahwa pengembangan tebal bambu lamina dari bambu andong adalah 1,03\%. Hal ini mungkin disebabkan oleh perbedaan perekat yang digunakan. Pada penelitian sebelumnya perekat yang digunakan adalah tanin resorsinol formaldehida yang termasuk perekat tipe eksterior sedangkan dalam penelitian ini perekat yang digunakan adalah urea formaldehida yang termasuk perekat tipe interior.

Pengembangan tebal bambu lamina 4 lapis yang dibuat dari pelupuh bambu moso dan direkat dengan perekat berbahan dasar resorsinol bervariasi antara $11,90 \%$ 12,40\% (Nugroho dan Ando, 2001). Pengembangan tebal lantai bambu yang diperdagangkan di pasaran Amerika Serikat dan bambu lamina 3 lapis yang dibuat di laboratorium dengan menggunakan bambu moso berturut-turut adalah 0,69\% dan 0,96\% (Lee dan Liu, 2003). Dari data tersebut dapat diketahui bahwa lantai bambu yang ada di pasaran Amerika Serikat memiliki pengembangan tebal yang sangat kecil. Hal ini terjadi karena produk lantai bambu tersebut sudah dilapisi bahan finishing sehingga air yang masuk kedalam produk tersebut hanya dapat melalui bagian atau permukaan yang tidak difinishing. Berdasarkan uraian di atas dapat diketahui juga bahwa bambu lamina yang dibuat dari bilah bambu lebih setabil dibanding bambu lamina yang dibuat dari pelupuh bambu karena nilai pengembangan tebalnya lebih kecil.

Pengembangan linier bambu lamina dari tiga jenis bambu berkisar antara 0,55\% - 0,76\% dengan rata-rata 0,65\%. Berdasarkan data pada Tabel 2 dapat diketahui bahwa 
jenis bambu berpengaruh nyata terhadap sifat pengembangan linier bambu lamina. Bambu lamina dari bambu andong memiliki nilai pengembangan linier terendah sedangkan bambu lamina dari bambu tali memiliki nilai pengembangan linier tertinggi. Sulastiningsih et al. (2005) menyatakan bahwa pengembangan linier bambu lamina dari bambu andong yang direkat dengan perekat tanin resorsinol formaldehida adalah 0,46\%. Hasil penelitian Nugroho dan Ando (2001) menunjukkan bahwa pengembangan linier bambu lamina 4 lapis yang dibuat dari pelupuh bambu moso dan direkat dengan perekat berbahan dasar resorsinol adalah 0,48\%.

Tabel 3. Hasil uji BNJ beberapa sifat bambu lamina

Table 3. HSD result on some properties of laminated bamboo board

\begin{tabular}{|c|c|c|c|c|}
\hline No & Sifat (Properties) & \multicolumn{3}{|c|}{$\begin{array}{l}\text { Nilai rata-rata yang dibandingkan } \\
\text { (Comparision of mean values) }\end{array}$} \\
\hline 1 & Kerapatan (Density), g/ $\mathrm{cm}^{3}$ & $\begin{array}{l}\mathrm{P} 2 \\
0,60\end{array}$ & $\begin{array}{l}\text { P3 } \\
0,76\end{array}$ & $\begin{array}{l}\mathrm{P} 1 \\
0,77\end{array}$ \\
\hline 2 & $\begin{array}{l}\text { Pengembangan tebal (Thickness } \\
\text { swelling) } \%\end{array}$ & $\begin{array}{l}\mathrm{P} 1 \\
3,31\end{array}$ & $\begin{array}{l}\mathrm{P} 2 \\
4,57 \\
\end{array}$ & $\begin{array}{l}\text { P3 } \\
6,63\end{array}$ \\
\hline 3 & $\begin{array}{l}\text { Pengembangan linier } \\
\text { (Linear expansion),\% }\end{array}$ & $\begin{array}{l}\mathrm{P} 1 \\
0,55\end{array}$ & $\begin{array}{c}\text { P2 } \\
0,66\end{array}$ & $\begin{array}{l}\text { P3 } \\
0,76\end{array}$ \\
\hline 4 & $\begin{array}{l}\text { Penyerapan air } \\
\text { (Water absorption), \% }\end{array}$ & $\begin{array}{l}\text { P1 } \\
18,37\end{array}$ & $\begin{array}{l}\text { P3 } \\
22,27\end{array}$ & $\begin{array}{l}\mathrm{P} 2 \\
26,03\end{array}$ \\
\hline 5 & $\begin{array}{l}\text { Modulus patah } \\
\text { (Modulus of rupture), } \mathrm{kg} / \mathrm{cm}^{2}\end{array}$ & $\begin{array}{l}\text { P2 } \\
1.107,24\end{array}$ & $\begin{array}{l}\mathrm{P} 1 \\
1.236,70\end{array}$ & $\begin{array}{l}\text { P3 } \\
1.410,18\end{array}$ \\
\hline 6 & $\begin{array}{l}\text { Modulus elastisitas } \\
\text { (Modulus of elasticity), kg/cm² }\end{array}$ & $\begin{array}{c}\mathrm{P} 2 \\
143.127\end{array}$ & $\begin{array}{c}\text { P3 } \\
172.672 \\
\end{array}$ & $\begin{array}{c}\mathrm{P} 1 \\
361.154\end{array}$ \\
\hline 7 & $\begin{array}{l}\text { Keteguhan tekan tegak lurus serat } \\
\text { (Compression strength } \\
\text { perpendicular to grain), } \mathrm{kg} / \mathrm{cm}^{2}\end{array}$ & $\begin{array}{l}\mathrm{P} 2 \\
1.153,64\end{array}$ & $\begin{array}{c}\text { P3 } \\
1.328,68\end{array}$ & $\begin{array}{l}\mathrm{P} 1 \\
1.408,40\end{array}$ \\
\hline
\end{tabular}

Keterangan (Remarks): P1 = Bambu andong (Gigantochloa pseudoarundinacea); 
P2 = Bambu mayan (Gigantochloa robusta); P3 = Bambu tali (Gigantochloa apus); ___ = Tidak berbeda nyata (Not significant difference)

Penyerapan air bambu lamina yang dibuat berkisar antara 18,37\% - 26,03\% dengan rata-rata 22,22\%. Jenis bambu berpengaruh nyata terhadap sifat penyerapan air bambu lamina (Tabel 2). Hasil uji beda pada Tabel 3 menunjukkan bahwa penyerapan air bambu lamina dari bambu andong (18,37\%) tidak berbeda nyata dengan penyerapan air bambu lamina dari bambu tali (22,27\%). Hal ini mungkin kerena bambu lamina dari bambu andong memiliki kerapatan yang hampir sama dengan bambu lamina dari bambu tali. Hasil penelitian Nugroho dan Ando (2001) menunjukkan bahwa penyerapan air bambu lamina 4 lapis yang dibuat dari pelupuh bambu moso dan direkat dengan perekat berbahan dasar resorsinol berkisar antara 24,10\% - 26,10\%.

Modulus patah bambu lamina yang dibuat berkisar antara 1.107,24 - 1.410,18 $\mathrm{kg} / \mathrm{cm}^{2}$ dengan rata-rata 1.251,37 kg/ $\mathrm{cm}^{2}$. Hasil sidik ragam pada Tabel 2 menunjukkan bahwa modulus patah bambu lamina dipengaruhi oleh jenis bambu. Bambu lamina dari bambu mayan memiliki nilai modulus patah terendah sedangkan bambu lamina dari bambu tali memiliki nilai modulus patah tertinggi.

Namun demikian berdasarkan hasil uji beda pada Tabel 3 dapat diketahui bahwa modulus patah bambu lamina dari bambu mayan $\left(1.107,24 \mathrm{~kg} / \mathrm{cm}^{2}\right)$ tidak berbeda nyata dengan modulus patah bambu lamina dari bambu andong $\left(1.236,70 \mathrm{~kg} / \mathrm{cm}^{2}\right)$. Modulus patah rata-rata bambu lamina 3 lapis dari pelupuh bambu betung yang direkat dengan perekat urea formaldehida adalah $1.031,25 \mathrm{~kg} / \mathrm{cm}^{2}$ (Sulastiningsih et al., 1996). Modulus patah rata-rata bambu lamina 3 lapis dari pelupuh bambu andong dengan perekat urea formaldehida adalah $1.001 \mathrm{~kg} / \mathrm{cm}^{2}$ (Sulastiningsih et al., 1998), sedangkan yang dibuat dari bilah bambu andong dan direkat dengan perekat tanin resorsinol formaldehida adalah $1.241 \mathrm{~kg} / \mathrm{cm}^{2}$ (Sulastiningsih et al., 2005). Hasil penelitian 
Nugroho dan Ando (2001) menunjukkan bahwa modulus patah bambu lamina 4 lapis yang dibuat dari pelupuh bambu moso dan direkat dengan perekat berbahan dasar resorsinol berkisar antara $639-707 \mathrm{~kg} / \mathrm{cm}^{2}$ (uji datar) dan antara $755-877 \mathrm{~kg} / \mathrm{cm}^{2}$ (uji tegak). Berdasarkan uraian di atas dapat diketahui bahwa bambu lamina yang dibuat dari bilah bambu lebih kuat dibanding bambu lamina yang dibuat dari pelupuh bambu karena nilai modulus patahnya lebih besar.

Dransfield dan Widjaja (1995) menyatakan bahwa modulus patah bambu andong dalam bentuk bundar adalah $171-207 \mathrm{~N} / \mathrm{mm}^{2}\left(1.743-2.110 \mathrm{~kg} / \mathrm{cm}^{2}\right)$, untuk bambu tali adalah $87,5 \mathrm{~N} / \mathrm{mm}^{2}$ atau $891,625 \mathrm{~kg} / \mathrm{cm}^{2}$ (kering udara dengan buku) dan $74,9 \mathrm{~N} / \mathrm{mm}^{2}$ atau $763,231 \mathrm{~kg} / \mathrm{cm}^{2}$ (kering udara tanpa buku), sedangkan modulus patah bambu mayan adalah $136 \mathrm{~N} / \mathrm{mm}^{2}$ atau 1.385,84 kg/ $\mathrm{cm}^{2}$. Hasil penelitian Idris et al. (1994) menunjukkan bahwa modulus patah bambu andong yang diuji dengan menggunakan contoh kecil bebas cacat adalah 1.032,6 kg/ $\mathrm{cm}^{2}$ (berbuku) dan 1.835,6 $\mathrm{kg} / \mathrm{cm}^{2}$ (tanpa buku), sedangkan untuk bambu tali adalah 502,3 kg/ $\mathrm{cm}^{2}$ (berbuku) dan 1.240,3 kg/cm² (tanpa buku). Sedangkan menurut Suryokusumo dan Nugroho (1994), modulus patah bambu andong yang diuji dengan menggunakan contoh kecil bebas cacat adalah $1.356 \mathrm{~kg} / \mathrm{cm}^{2}$.

Modulus elastisitas bambu lamina yang dibuat berkisar antara 143.127 $361.154 \mathrm{~kg} / \mathrm{cm}^{2}$ dengan rata-rata $225.651 \mathrm{~kg} / \mathrm{cm}^{2}$. Modulus elastisitas bambu lamina sangat dipengaruhi oleh jenis bambu yang digunakan (Tabel 2). Bambu lamina dari bambu mayan memiliki nilai modulus elastisitas terendah sedangkan bambu lamina dari bambu andong memiliki nilai modulus elastisitas tertinggi. Berdasarkan hasil uji beda pada Tabel 3 dapat diketahui bahwa modulus elastisitas bambu lamina dari bambu mayan $\left(143.127 \mathrm{~kg} / \mathrm{cm}^{2}\right)$ tidak berbeda nyata dengan modulus elastisitas bambu lamina dari bambu tali $\left(172.672 \mathrm{~kg} / \mathrm{cm}^{2}\right)$. Hasil penelitian terdahulu menunjukkan bahwa 
modulus elastisitas bambu lamina 3 lapis dari pelupuh bambu betung dan bambu andong dengan perekat urea formaldehida berturut-turut adalah $175.592 \mathrm{~kg} / \mathrm{cm}^{2}$ dan $151.500 \mathrm{~kg} / \mathrm{cm}^{2}$ (Sulastiningsih et al., 1996 dan 1998), sedangkan yang dibuat dari bilah bambu andong dan direkat dengan perekat tanin resorsinol formaldehida adalah $133.615 \mathrm{~kg} / \mathrm{cm}^{2}$ (Sulastiningsih et al., 2005). Hasil penelitian Nugroho dan Ando (2001) menunjukkan bahwa modulus elastisitas bambu lamina 4 lapis yang dibuat dari pelupuh bambu moso dan direkat dengan perekat berbahan dasar resorsinol berkisar antara 96,2 - $107 \times 10^{3} \mathrm{~kg} / \mathrm{cm}^{2}$ (uji datar) dan antara $111-123 \times 10^{3} \mathrm{~kg} / \mathrm{cm}^{2}$ (uji tegak).

Dransfield dan Widjaja (1995) menyatakan bahwa modulus elastisitas bambu andong adalah $19.440-28.594 \mathrm{~N} / \mathrm{mm}^{2}\left(198.093-291.373 \mathrm{~kg} / \mathrm{cm}^{2}\right)$, sedangkan modulus elastisitas bambu mayan adalah $9.829 \mathrm{~N} / \mathrm{mm}^{2}\left(100.157 \mathrm{~kg} / \mathrm{cm}^{2}\right)$. Hasil penelitian Idris et.al (1994) menunjukkan bahwa modulus elastisitas bambu andong $96.616 \mathrm{~kg} / \mathrm{cm}^{2}$ (berbuku) dan $121.395 \mathrm{~kg} / \mathrm{cm}^{2}$ (tanpa buku), sedangkan untuk bambu tali adalah $57.515 \mathrm{~kg} / \mathrm{cm}^{2}$ (berbuku) dan $121.334 \mathrm{~kg} / \mathrm{cm}^{2}$ (tanpa buku).

Keteguhan tekan sejajar serat bambu lamina yang dibuat berkisar antara 594,65 - 700,88 kg/cm ${ }^{2}$ dengan rata-rata 634,27 kg/cm². Hasil sidik ragam pada Tabel 2 menunjukkan bahwa jenis bambu tidak berpengaruh nyata terhadap sifat keteguhan tekan sejajar serat bambu lamina. Hasil penelitian Idris et al. (1994) menunjukkan bahwa keteguhan tekan bambu andong adalah 562,2 kg/cm² (berbuku) dan 631,1 $\mathrm{kg} / \mathrm{cm}^{2}$ (tanpa buku), sedangkan keteguhan tekan bambu tali adalah 505,3 kg/ $\mathrm{cm}^{2}$ (berbuku) dan 521,3 kg/cm² (tanpa buku). Menurut Suryokusumo dan Nugroho (1994) keteguhan tekan sejajar serat bambu andong adalah $521 \mathrm{~kg} / \mathrm{cm}^{2}$. Sedangkan menurut Dransfield dan Widjaja (1995) keteguhan tekan sejajar serat bambu tali adalah 37,5 $\mathrm{N} / \mathrm{mm}^{2}$ atau 382,125 kg/cm² (kering udara dengan buku) dan 33,9 N/mm² atau 345,44 $\mathrm{kg} / \mathrm{cm}^{2}$ (kering udara tanpa buku), dan keteguhan tekan bambu mayan adalah $52 \mathrm{~N} / \mathrm{mm}^{2}$ 
atau $529,88 \mathrm{~kg} / \mathrm{cm}^{2}$.

Keteguhan tekan tegak lurus serat bambu lamina yang dibuat berkisar antara $1.153,64-1.408,40 \mathrm{~kg} / \mathrm{cm}^{2}$ dengan rata-rata $1.296,91 \mathrm{~kg} / \mathrm{cm}^{2}$. Hasil sidik ragam pada Tabel 2 menunjukkan bahwa keteguhan tekan tegak lurus serat bambu lamina dipengaruhi oleh jenis bambu yang digunakan. Bambu lamina dari bambu mayan memiliki nilai keteguhan tekan tegak lurus serat terendah sedangkan bambu lamina dari bambu andong memiliki nilai keteguhan tekan tegak lurus serat tertinggi.

Jika nilai kerapatan, keteguhan lentur dan keteguhan tekan bambu lamina dibandingkan dengan pembagian kelas kuat kayu Indonesia (Oey Djoen Seng, 1964), maka bambu lamina (3 lapis) masing-masing dari bambu andong, mayan dan tali setara dengan kayu kelas kuat II. Hasil penelitian ini sejalan dengan hasil penelitian sebelumnya (Sulastiningsih et al., 2005).

Keteguhan rekat bambu lamina yang diuji degan cara geser tekan berkisar antara $67,03-86,19 \mathrm{~kg} / \mathrm{cm}^{2}$ dengan rata-rata $77 \mathrm{~kg} / \mathrm{cm}^{2}$ (uji kering) dan pada keadaan basah berkisar antara 54,43-62,94 kg/ $\mathrm{cm}^{2}$ dengan rata-rata 58,83 kg/ $\mathrm{cm}^{2}$. Hasil sidik ragam pada Tabel 2 menunjukkan bahwa jenis bambu tidak berpengaruh nyata terhadap keteguhan rekat bambu lamina baik yang diuji dalam keadaan kering maupun basah. Menurut Standar Jepang (Anonim, 2003) persyaratan keteguhan rekat kayu lamina yang diuji dengan cara geser tekan dalam keadaan kering bervariasi antara 55,08 - 97,92 $\mathrm{kg} / \mathrm{cm}^{2}$, tergantung dari kelompok jenis kayu yang digunakan. Berdasarkan uraian tersebut maka keteguhan rekat bambu lamina dari tiga jenis bambu semuanya memenuhi syarat standar Jepang karena nilai keteguhan gesernya lebih besar dari persyaratan yang ditentukan.

\section{KESIMPULAN}


1. Sifat fisis dan mekanis bambu lamina dipengaruhi oleh jenis bambu yang digunakan kecuali kadar air, keteguhan tekan sejajar serat dan keteguhan rekat.

2. Berdasarkan kerapatan, keteguhan lentur dan keteguhan tekan, bambu lamina dari bambu andong, mayan dan tali setara dengan kayu kelas kuat II.

3. Sifat perekatan bambu lamina dari bambu andong, mayan dan tali cukup baik, karena nilai keteguhan rekatnya memenuhi persyaratan menurut Standar Jepang untuk kayu lamina.

4. Pembuatan bambu lamina secara teknis dapat dilakukan. Bambu lamina dapat digunakan sebagai bahan substitusi kayu.

\section{DAFTAR PUSTAKA}

Anonim.1995. Standard test methods for evaluating properties of wood-based fiber and particle panel materials. Annual Book of ASTM Standard. ASTM D 1037-93. Philadelphia.

1999. Kayu lapis struktural. Badan Standardisasi Nasional. Jakarta. SNI 015008.7-1999.

2000. Kayu lapis penggunaan umum. Badan Standardisasi Nasional. Jakarta. SNI 01-5008.2-2000.

2003. Japanese Agricultural Standard for Glued Laminated Timber. The Japan Plywood Inspection Corporation, Tokyo

. 2006. Statistik Indonesia 2005/2006. Katalog BPS: 1401. Badan Pusat Statistik. Jakarta. Indonesia.

Dransfield, S. and E.A. Widjaya (editors). 1995. Plant Resources of South East Asia No 7. Bamboos. Prosea Foundation, Bogor. 
Idris,A. A., A. Firmanti \& Purwito. 1994. Penelitian Bambu Untuk Bahan Bangunan. Strategi Penelitian Bambu Indonesia. Yayasan Bambu Lingkungan Lestari, Bogor. Hlm. 73-81.

Lee,A.W.C. \& Y. Liu. 2003. Selected physical properties of commercial bamboo flooring. Forest Products Journal 53(6): 23-26.

Nugroho, N. \& N. Ando. 2001. Development of structural composite products made from bamboo II: fundamental properties of laminated bamboo lumber. Journal of Wood Science 47(3):237-242.

Oey Djoen Seng. 1964. Berat Jenis dari Jenis-Jenis Kayu Indonesia dan Pengertian Beratnya Kayu untuk Keperluan Praktek. Pengumuman LPHH No 1. Bogor.

Sulastiningsih, I.M., Nurwati dan P. Sutigno. 1996. Pengaruh jumlah lapisan terhadap sifat bambu lamina. Buletin Penelitian Hasil Hutan 14(9): 366-373. Pusat Penelitian dan Pengembangan Hasil Hutan \& Sosial Ekonomi Kehutanan. Bogor. Indonesia.

Sulastiningsih, I.M., A. Santoso and T.Yuwono. 1998. Effect of position along the culm and number of preservative brushing on physical and mechanical properties of laminated bamboo. Proceedings Pacific Rim Bio-Based Composites Symposium. November 2-5, 1998, Bogor, Indonesia. Pp. 106 - 113. Faculty of Forestry, Bogor Agricultural University. Bogor.

Sulastiningsih, I.M., Nurwati \& A. Santoso.2005. Pengaruh lapisan kayu terhadap sifat bambu lamina. Jurnal Penelitian Hasil Hutan 23(1): 15-22. Pusat Penelitian dan Pengembangan Hasil Hutan. Bogor. Indonesia.

Supriana, N., S. Abdurrohim, Barly, Jasni, Djarwanto, J. Malik, M. Muslich, D. Martono dan P. Permadi. 2003. Kajian peran pengawetan kayu perumahan dan gedung dalam rangka pengelolaan hutan lestari. Laporan Hasil Penelitian Pusat Penelitian dan Pengembangan Teknologi Hasil Hutan, Bogor. Tidak terbit. 
Suryokusumo, S. \& N. Nugroho. 1994. Pemanfaatan Bambu Sebagai Bahan Bangunan. Strategi Penelitian Bambu Indonesia. Yayasan Bambu Lingkungan Lestari, Bogor. Hlm. 82-87. 